\title{
Hak Asasi Manusia Versus Pidana Mati
}

\author{
Boni Wuarlela ${ }^{1}$, Reski Wijaya², Ansyari Imran ${ }^{3}$, Nurul Ramadhani ${ }^{4}$
}

\begin{abstract}
Human Rights are the basic rights of every human being as God's creatures who are equal to one another. The application of the death penalty by the state through a court decision means that the state revokes the convict's right to life which is an unlimited human right. Therefore, its implementation must take into account the rights of the convict. The purpose of this paper is to find out whether the imposition of the death penalty for criminals is against human rights. What are the criteria for imposing the death penalty for perpetrators of crimes that do not conflict with human rights? The method used is a normative research method using secondary data. It can be concluded that the imposition of the death penalty is against human rights. However, in its application, it can be justified on the grounds of defending human rights and only for crimes that go beyond humanity and damage human civilization. The implementation of the criminal justice process must be transparent and fair.
\end{abstract}

Keywords: Protection of Human Rights, Rule of Law, Death Penalty

\section{Latar Belakang Masalah}

Pro dan kontra mengenai hukuman mati seolah-olah tidak menemui titik akhir dalam perdebatan. Hal ini mengundang berbagai macam reaksi dan pendapat dari para ahli hukum dan pengiat hak asasi manusia hingga masyarakat. Oleh karena itu, konsistensi penerapan pidana mati di dunia selalu saja menjadi suatu hal yang kontroversial, baik di kalangan pemerintah, praktisi hukum, agamawan maupun masyarakat sendiri. Karena hukuman mati dianggap melanggar hak yang paling mendasar bagi manusia yaitu hak untuk hidup dan memperbaiki kehidupannya.

Hukuman mati merupakan jenis pidana yang terberat dibandingkan dengan pidana lainnya, karena dengan pidana mati terenggut jiwa manusia untuk mempertahankan hidupnya. Hukuman mati juga bentuk hukuman keji yang memberikan efek jera kepada pelaku kejahatan. Sayangnya hukuman ini juga melanggar hak untuk hidup yang diatur dalam Deklarasi Universal Hak Asasi Manusia atau Universal Declaration of Human Rights (DUHAM). Pidana mati merupakan salah satu dari jenisjenis pidana yang terdapat di dalam Kitab Undang-Undang Hukum Pidana, yang merupakan pidana pokok yang terberat. Bambang Poernomo mengatakan : "Pidana mati merupakan salah satu bentuk pidana yang paling tua, sehingga dapat juga dikatakan bahwa pidana mati itu sudah tidak sesuai dengan kehendak zaman, namun

\footnotetext{
1 Sekolah Tinggi Ilmu Hukum Amsir, Boni Suparto Wuarlela, boniwuarlela08@gmail.com

2 Sekolah Tinggi Ilmu Hukum Amsir, Reski Wijaya, reskiwijaya24@gmail.com

${ }^{3}$ Sekolah Tinggi IImu Hukum Amsir, Ansyari Imran, ansyari.imran@gmail.com

4 Sekolah Tinggi Ilmu Hukum Amsir, Nurul Ramadhani, nurulramadhani99@gmail.com
} 
sampai pada saat ini belum diketemukan alternatif lain sebagai penggantinya". ${ }^{5}$

Pidana mati adalah sarana untuk melindungi kepentingan umum yang bersifat kemasyarakatan yang dibahayakan oleh kejahatan dan penjahat yang sudah tidak dapat diperbaiki lagi. Sesuai dengan perkembangan hukum pidana yang modern yang menyusun pidana untuk melindungi kepentingan masyarakat dan kepentingan perseorangan yang menjadi korban dari kejahatan dan penjahat.

Roeslan Saleh mengatakan : "Pidana mati merupakan jenis pidana yang yang terberat menurut hukum positif kita. Bagi kebanyakan negara soal pidana mati itu tinggal mempunyai arti kulturhistoris. Dikatakan demikian, karena kebanyakan negara-negara tidak mencantumkan pidana mati ini lagi di dalam Kitab Undang-Undang Hukum Pidananya". ${ }^{6}$

Pidana mati merupakan pidana yang paling banyak dipersoalkan. Mereka yang pro pidana mati mengemukakan alasan-alasan untuk membela pendapatnya demikian juga mereka yang kontra pidana mati mengemukakan alasan mereka antara lain bahwa nyawa adalah milik yang paling berharga bagi manusia. Hilangnya nyawa berarti hilangnya manusia itu sendiri. Memang dalam kenyataannya, banyak negara yang sudah menghapus pidana mati dalam Kitab Undang-Undang Hukum Pidana mereka, namun ada juga beberapa negara termasuk Indonesia yang masih mempertahankan pidana mati dengan berbagai alasan dan pertimbangan.

Hak asasi manuasia merupakan hak-hak dasar yang dimiliki oleh setiap manusia untuk memperoleh perlindungan dari negara. Perlindungan dari hak-hak asasi manusia ini tidak akan terjamin dengan hanya menyatakan bahwa hak-hak asasi manusia ini diakui, yang diperlukan ialah suatu persediaan yang lebih konkrit. ${ }^{7}$

Berdasarkan latar belakang masalah ini, maka akan dibahas mengenai bagaimana hukum memandang perlindungan hak asasi manusia dan sebaliknya, khususnya pidana mati yang dianggap bertentangan dengan "hak untuk hidup" sebagai salah satu hak asasi manusia.

Yang membuat penulisan ini menarik adalah pembahasan dalam jurnal ini fokus kepada pidana mati serta bagaimana pertikaian dari kedua pandangan antara Hak Asasi Manusia dengan Hukum Pidana khususnya Pidana Mati yang membantu kita agar dapat jauh memahami fungsi serta tujuan diadakan ataupun dihilangkannya Pidana Mati dalam sebuah hukum yang berlaku.

\section{Metode Penelitian}

5 Bambang Poernomo, Hukum Pidana Kumpulan Karangan Ilmiah, Bina Aksara, Jakarta, 1982, hal.9

${ }^{6}$ Roeslan Saleh, Stelsel Pidana Indonesia, Aksara Baru, Jakarta, 1987, hal.16.

7 Sudargo Gautama (gouwgioksiong), Pengertian Tentang Negara Hukum, Alimni, Bandung 1973, hal.10. 
Metode penelitian ini menggunakan metode penelitian normatif, yakni penelitian hukum normatif merupakan penelitian hukum yang dilakukan dengan cara meneliti bahan pustaka atau data sekunder. Penelitian hukum normatif disebut juga penelitian hukum doktrinal. Penelitian yang dilakukan bersifat deskriptif analitis yaitu menggambarkan, menganalisis, menyimpulkan masalah-masalah yang menjadi objek penelitian. ${ }^{8}$

\section{Analisis Dan Pembahasan}

\section{A.Hukuman Mati dalam Prespektif Hak Asasi Manusia}

Secara historis, kemunculan Hak Asasi Manusia (HAM) adalah proses pembelaan kepada masyarakat atas tindakan sewenang-wenangan yang dilakukan oleh negara dan juga karena tidak seimbangnya posisi negara dengan masyarakat. ${ }^{9}$ Dalam perspektif Universal Declaration Of Human Rights, hukuman mati dilarang. ${ }^{10} \mathrm{Hal}$ ini sesuai dengan ketentuan pada Pasal 3 Deklarasi Universal yang berbunyi: "every human being has the right to life. This right shall be protected by law. No one shall be arbitrarily deprived of his life". (Setiap orang mempunyai hak atas penghidupan, kemerdekaan dan keselamatan seseorang).

Ketentuan dalam DUHAM ini kemudian dipertegas dalam kovenan di bidang hakhak sipil dan politik yaitu Pasal 6 ayat 1 dan Pasal 7 International Covenant on Civil and Political Rights-(ICCPR) sekaligus dikuatkan lagi oleh Protocol Opsional Kedua atas Perjanjian Internasional Mengenai Hak-hak Sipil dan Politik Tahun 1989 tentang Penghapusan Hukuman Mati.

Point penting dalam Isi dari Pasal 6 Kovenan Internasional tentang Hak Sipil dan Politik yaitu bahwa Setiap manusia berhak atas hak untuk hidup yang melekat pada dirinya.Hak ini wajib dilindungi oleh hukum. Tidak seorang pun dapat dirampas hak hidupnya secara sewenang-wenang. Dan bagi Negara yang belum menghapuskan hukuman mati, putusan hukuman mati hanya dapat dijatuhkan terhadap beberapa

8 Syahruddin Nawi. 2017. Penelitian Hukum Normatif Versus Penelitian Hukum Empiris. PT. Umitoha Ukhuwah Grafika. Hal.9

9 Syamsul Haling, et.all., 2018, Perlindungan Hak Asasi Anak Jalanan dalam Bidang Pendidikan Menurut Hukum Nasional dan Konvensi Internasional, Jurnal Hukum \& Pembangunan, hal. 365.

10 Saharuddin Daming, 2016, Konfigurasi Pertarungan Abolisionisme Versus Retensionisme dalam Diskursus Keberadaan Lembaga Pidana Mati di Tingkat Global dan Nasional, Yustisi, hal.40. 
kejahatan yang paling serius sesuai dengan hukum yang berlaku pada saat dilakukannya kejahatan tersebut

Sedangkan dalam Pasal 7 Kovenan Internasional tentang Hak Sipil dan Politik, di dalam Pasal ini juga menjadi sebuah pendukung bahwa tidak dapat perlakukan seseorang dengan sewenang-wenang dalam hal tindakan yang tidak manusiawi yang kemungkinan dapat menghilangkan nyawa seseorang dan tanpa ada persetujuan.

Pada beberapa instrumen HAM, larangan hukuman mati dimuat dalam sebuah protokol tersendiri. Kovenan Internasional tentang Hak-hak Sipil dan Politik dan Konvensi Amerika, keduanya membatasi hukuman mati pada "kejahatan yang paling berat." Keduanya mengatur bahwa hukuman mati harus hanya boleh dikenakan oleh sesuatu "keputusan final suatu pengadilan yang berwenang" sesuai dengan undangundang yang tidak retroaktif. ${ }^{11}$

Intisari dari hukuman mati dalam perspektif DUHAM adalah dilarang, Dalam pandangan HAM versi PBB, penerapan hukuman mati digolongkan sebagai bentuk hukuman yang kejam/keji dan tidak manusiawi, melanggar Pasal 3 Universal Declaration of Human Rights dan Pasal 7 (International Covenant on Civil and Political RightsICCPR). Berdasarkan kovenan tersebut sekalipun asasnya dilarang tetapi jika ada negara-negara yang masih memperlakukan/belum menghapuskan hukuman mati hanya terbatas diperlakukan kepada kejahatan/atau tindak pidana tertentu (khusus/serius) seperti kejahatan genosida atau terorisme (Pasal 6 ayat 2 International Covenant on Civil and Political Rights-ICCPR).

Negara Indonesia akhir-akhir ini mulai mengadopsi pemikiran yang berkembang di dunia tentang HAM, dan mengadopsi DUHAM PBB masuk dalam konstitusi dan juga dalam Undang-Undang Nomor 39 Tahun 1999 tentang Hak Asasi Manusia, sekaligus pembentukan Komisi Nasional Hak Asasi Manusia (Komnas HAM). Pada Konstitusi Republik Indonesia setelah perubahan (amandemen) termaktub dalam Pasal 28A, Hak untuk hidup serta mempertahankan hidup dan kehidupan (Pasal 28A) mirip sekali dengan isi dari Pasal 3 DUHAM PBB.

Ketentuan dalam Pasal 28A UUD RI 1945 tersebut kemudian dirinci dalam Undang-Undang No. 39 Tahun 1999 tentang Hak Asasi Manusia. Pada Bab III: Hak Asasi Manusia dan Kebebasan Dasar Manusia; Bagian Kesatu, Hak untuk Hidup pada Pasal

11 Habib Shulton Asnawi, 2012, Hak Asasi Manusia Islam dan Barat: Studi Kritik Hukum Pidana Islam dan Hukuman Mati, Supremasi Hukum, hlm. 26. 
9 yang kurang lebihnya membahas tentang Hidup dan Kehidupan maupun lingkungan hidup seseorang.

Selanjutnya dalam Bab IV: Kewajiban Dasar Manusia; Pasal 67 membahas tentang setiap warga negara Indonesia harus patuh kepada setiap peraturan yang berlaku termasuk hukum internasional tentang Hak Asasi Manusia. Pasal 69 Undangundang nomor 39 Tahun 1999 tentang Hak Asasi Manusia kurang lebihnya membahas bahwa setiap orang harus menghormati hak asasi manusia yang lain dan menjadi tugas pemerintah untuk melindungi hak asasi manusia ini.

Selanjutnya pada Pasal 70 Undang-undang nomor 39 Tahun 1999 Tentang Hak Asasi Manusia mengharuskan setiap orang untuk patuh terhadap pembatasan yang ditetapkan oleh Undang-undang agar menjamin pengakuan serta penghormatan hak dan kebebasan orang lain.

\section{B.Pandangan Hak Asasi Manusia Terhadap Beberapa Kriteria Penjatuhan Pidana Mati}

Penegakan hukum adalah proses dilakukannya upaya untuk tegaknya atau berfungsinya norma-norma hukum secara nyata sebagai pedoman perilaku hubungan hukum dalam kehidupan bermasyarakat dan bernegara. Ditinjau dari sudut subyeknya, penegakan hukum itu dapat dilakukan oleh subyek yang luas dan dapat pula diartikan sebagai upaya penegakan hukum itu melibatkan semua subyek hukum dalam setiap hubungan hukum. Siapa saja yang menjalankan aturan normatif atau melaksanakan sesuatu atau tidak melakukan sesuatu dengan mendasarkan diri pada norma aturan hukum yang berlaku, berarti dia menjalankan atau menegakkan aturan hukum. Dalam arti sempit, dari segi subyeknya itu, penegakan hukum itu hanya diartikan sebagai upaya aparatur penegak hukum tertentu untuk menjamin dan memastikan tegaknya hukum itu. $^{12}$

Hukum pidana pada dasarnya merupakan sarana untuk menjamin terlindunginya dan tercapainya ketertiban sosial dalam masyarakat. Sedangkan di Indonesia sendiri tujuan dari hukum pidana itu diorientasikan pada aspek social welfare dan social defence, sebagaimana yang termaktub dalam tujuan negara yang terdapat dalam alinea keempat

12 Ayub Torry Satriyo Kusumo, Hukuman Mati Ditinjau Dari Perspektif Hukum dan Hak Asasi Manusia, 2015 
Undang-undang Dasar $1945 .^{13}$

Penjatuhan pidana adalah bagian yang berperan dalam proses pengadilan pidana. Maka dari itu pelaksanaannya harus mendasarkan pada perspektif humanistis dan tujuan pidana integratif serta aliran pemidanaan modern yang mengutamakan perlindungan masyarakat. Perspektif humanistis menekankan pada syarat penjatuhan pidana yang meliputi perbuatan pidana (actus reus) dan pertanggungjawaban pidana (mens rea). Dalam hukum pidana biasa disebut hukum pidana yang menekankan pada perbuatan (strajbaar heid van hetfeit) dan hukum pidana yang menekankan pada orang (strafbaar heid van de person).

Hukum yang mengatur tentang perbuatan-perbuatan apa yang diancam pidana dan dimana aturan pidana itu menjelma disebut hukum pidana. Oleh karena itu, hukum pidana disebut sebagai Hukum Sanksi Istimewah. Penjatuhan pidana sebagai penderitaan kepada pelanggar hanya merupakan jalan terakhir yang hanya dijalankan apabila usaha-usaha lain seperti pencegahan sudah tidak berjalan. Salah satu bentuk pidana yang paling berat adalah Pidana Mati ${ }^{14}$.

Dalam sebuah aturan yang dibuat maupun diterapkan haruslah berlandaskan atas landasan Filosofis, Landasan Sosiologis dan Landasan Yuridis serta aturan yang baik harus mampu mengikuti perkembangan sebuah Negara di mana aturan itu berlaku dan tidak multi tafsir. Landasan Sosiologis sendiri ialah pertimbangan atau alasan yang menggambarkan bahwa peraturan yang dibentuk untuk memenuhi kebutuhan masyarakat dalam berbagai aspek. Namun kenyataannya jika sebuah aturan yang dijalankan atau diterapkan masih terdapat berbagai kritikan di tengah masyarakat maka dapat dikatakan salah salu landasan belum terpenuhi.

Mengenai proses serta langkah yang sepatutnya diambil oleh pihak yang beracara di pengadilan dalam menjalankan aturan khususnya tindak pidana yang mengakibatkan hak asasi manusia ada yang dilanggar perlu ditinjau kembali lalu kemudian direvisi sehingga menjadi sebuah keputusan maupun aturan yang mampu memberikan jalan tengah antara Hak Asasi Manusia dengan Kitab Undang-undang Hukum Pidana. Mengingat jelas bahwa dalam Undang-undang Dasar Tahun 1945 serta Undang-undang Nomor 39 Tahun 1999 Tentang Hak Asasi Manusia berusaha

13 Ferawati, 2015, Kajian Hukum dan HAM Terhadap Penjatuhan Pidana Mati Bagi Terpidana Narkotika, Jurnal IImu Hukum, hal. 139.

14 Aulia Andika Rukman, Pidana Mati dari Prespektif Sosiologis dan Penegakan HAM, Hal. 123 
mewujudkan piagam Hak Asasi Manusia Perserikatan Bangsa-bangsa untuk menghapuskan hukuman mati, tetapi masih tetap memberlakukan hukuman mati tersebut hanya pada beberapa kasus kejahatan luar biasa.

Ada 3 hal yang menjadi titik pembicaraan dalam hukum pidana yaitu tindak pidana (actus reus), pertanggungjawaban pidana (mens rea), dan pengenaan pidana. Penerapan pidana dalam perspektif humanistis harus berdasarkan pada kesalahan pelaku atau yang dikenal dengan asas culpabilitas. Asas ini menyatakan bahwa Nulfa Poena Sine Culpa yang artinya tiada pidana tanpa kesalahan dari pelaku. Kesalahan dimanifestasikan dalam sikap batin tindak pidana yang berupa dengan sengaja atau dengan kealpaan. Adanya penerapan dualistis dalam mengkaji unsur tindak pidana, maka tidak ada tempat bagi kedua bentuk sikap batin/mental tersebut menjadi bagian inti dari tindak pidana.

Hal ini menjadi tugas pengadilan sebagai garda terdepan penjatuhan pidana, agar dalam menjatuhkan pidana mati harus benar-benar dapat membuktikan ada atau tidaknya kesalahan terpidana melalui proses pengadilan yang adil dan pembuktian yang faktual berdasarkan undangundang. Tujuan pemidanaan integratif dalam menjatuhkan pidana terutama pidana mati, harus memperhatikan faktor-faktor yang menyangkut Hak Asasi Manusia terpidana, dan menjadikan pidana bersifat operasional dan fungsional. Oleh karena itu pendekatan multi dimensional untuk dapat melihat dampak pemidanaan individual maupun sosial.

Dalam beberapa kriteria tindak pidana yang dianggap patut untuk dijatuhi hukuman pidana matipun perlu diperbarui agar kriteria tersebut dapat diterima baik di tengah masyarakat maupun semua kalangan khusus para aktifis Hak Asasi Manusia atau pihak yang kontra dengan diberlakukannya hukuman mati. Walaupun benar bahwa hukuman mati menurut para pihak yang pro dengan diberlakukannya hukuman mati tersebut bertujuan demi melindungi masyarakat serta menghindari Negara dari berbagai tindak pidana yang bisa merugikan serta mengancam peradaban manusia.

Penjatuhan pidana mati dapat dikalkulasi terhadap dampaknya bagi perlindungan masyarakat (defense social) dan bagi terpidana sendiri. Aliran modern pemidanaan menekankan pada doktrin determinisme dimana manusia dianggap tidak mempunyai kebebasan kehendak, tapi kehendak manusia dipengaruhi oleh watak dari pelaku dan motif dari lingkungan di luar pelaku. Sehingga manusia tidak dapat dipertanggungjawabkan dan menolak pembalasan berdasarkan kesalahan subyektif. Bentuk pertanggungjawaban berupa tindakan bersifat perlindungan masyarakat. 
Berdasarkan pada konsep tersebut di atas maka dalam menerapkan pidana mati terhadap pelaku kejahatan dengan mengedepankan kriteria tindak pidana yang dilakukan sebagai berikut: (1) melampaui batas kemanusiaan, (2) mencelakai dan mengancam banyak manusia, (3) merusak generasi bangsa, (4) merusak peradaban bangsa, (5) merusak tatanan di muka bumi, (6) merugikan serta menghancurkan perekonomian negara. Jenis tindak pidana ini meliputi: narkoba, terorisme, pembunuhan berencana, penganiayaan berakibat mati secara sadis serta kejam dan tindak piadana korupsi.

Penjatuhan pidana mati harus tetap memperhatikan hal-hal sebagai berikut: (1) proses peradilan dilakukan dengan adil dan atas dasar pembuktian yang faktual, (2) kesalahan terpidana harus benar-benar dibuktikan di pengadilan, (3) pengadilan yang memproses merupakan pengadilan yang berwenang, (4) hukum yang digunakan harus hukum yang sah, (5) hukuman mati dijatuhkan secara selektif dan telah berkekuatan hukum tetap, (6) terpidana mati didampingi rohaniawan sejak putusan bersifat tetap hingga menjelang eksekusi, (7) permintaan terakhir terpidana mati harus dapat dipenuhi oleh negara, (8) eksekusi dilaksanakan setelah semua hak-hak terpidana mati terpenuhi, (9) eksekusi dilaksanakan seeklusif mungkin dan tanpa menimbulkan penderitaan terpidana, (10) jenazah diperlakukan sebagaimana layaknya manusia tanpa mengadakan pembedaan.

Misalnya pada sebuah kasus penjatuhan hukuman mati terhadap tersangka kasus narkoba, yang dipandang sangat merugikan bagi tersangka karena tersangka ini juga adalah manusia yang sudah jelas memiliki hak untuk hidup, yang sebenarnya hukuman tersebut dapat digantikan dengan hukuman pidana lainnya seperti pidana penjara dalam hal membimbing serta membina tersangka untuk dapat pulih dari keadaannya dengan cara direhabilitas di lembaga pemasyarakatan mengingat salah satu tugas Negara yaitu melindungi setiap Hak Asasi Manusia bagi setiap warga negaranya.

\section{Penutup}

Terdapat berbagai pandangan dari pemikiran para ahli hukum. Perspektif para aktifis hak asasi manusia dianggap sebagai pelanggaran Hak Asasi Manusia, karena termasuk hukum yang kejam, melanggar hak hidup manusia, sebagaimana diatur dalam Universal Declaration of Human Rights dan kovenan tentang hak-hak sipil dan politik. Hukuman mati dalam pandangan Hak Asasi Manusia yang ada dalam Undang-undang 
Dasar tahun 1945 dan Undang-undang Nomor 39 Tahun 1999 Tentang Hak Asasi Manusia berusaha mengadopsi piagam Hak Asasi Manusia Perserikatan Bangsabangsa untuk menghapuskan hukuman mati, tetapi masih tetap memberlakukan hukuman mati pada beberapa kasus kejahatan luar biasa. Dalam Kitab Undang-undang Hukum Pidana dan beberapa peraturan perundang-undangan di Indonesia, ancaman pidana mati masih tetap dipertahankan, walaupun mendapat kritikan dari para aktifis Hak Asasi Manusia. Oleh karena itu, dalam Rancangan Kitab Undang-undang Hukum Pidana yang baru ada semacam kompromi, dengan menjadikan hukuman mati bukan sebagai pidana pokok tetapi sebagai pidana alternatif yang diperlakukan hanya bagi kejahatan luar biasa.

\section{Daftar Pustaka}

Agus Widodo, Telaah Terhadap Perlindungan Hak Asasi Manusia dalam Negara Hukum Indonesia

Aulia Andika Rukman, Pidana Mati dari Prespektif Sosiologis dan Penegakan HAM, Hal. 123

Ayub Torry Satriyo Kusumo, Hukuman Mati Ditinjau Dari Perspektif Hukum dan Hak Asasi Manusia, 2015

Bambang Poernomo, Hukum Pidana Kumpulan Karangan Ilmiah, Bina Aksara, Jakarta,1982,hal.9

Ferawati, 2015, Kajian Hukum dan HAM Terhadap Penjatuhan Pidana Mati Bagi Terpidana Narkotika, Jurnal Ilmu Hukum, hal. 139.

Habib Shulton Asnawi, 2012, Hak Asasi Manusia Islam dan Barat: Studi Kritik Hukum Pidana Islam dan Hukuman Mati, Supremasi Hukum, hal. 26.

Roeslan Saleh, Stelsel Pidana Indonesia, Aksara Baru, Jakarta, 1987, hal.16.

Saharuddin Daming, 2016, Konfigurasi Pertarungan Abolisionisme Versus Retensionisme dalam Diskursus Keberadaan Lembaga Pidana Mati di Tingkat Global dan Nasional, Yustisi, hal.40.

Sudargo Gautama, (gouwgioksiong), Pengertian Tentang Negara Hukum, Alimni, Bandung 1973, hal.10.

Syahruddin Nawi. 2017. Penelitian Hukum Normatif Versus Penelitian Hukum Empiris. 
PT. Umitoha Ukhuwah Grafika. Hal.9.

Syamsul Haling, et.all., 2018, Perlindungan Hak Asasi Anak Jalanan dalam Bidang Pendidikan Menurut Hukum Nasional dan Konvensi Internasional, Jurnal Hukum \& Pembangunan, hal. 365.

\section{Internet :}

https://media.neliti.com/media/publications/151763-ID-pelaksanaan-pidana-matimenurut-undang-u.pdf, diakses pada tanggal 25 April 2021

https://media.neliti.com/media/publications/61161-ID-pidana-mati-ditinjau-dariprespektif-sos.pdf, diakses pada tanggal 02 Juni 2021

\section{Peraturan Perundang-Undang}

Undang-undang Dasar 1945.

Kitab Undang-undang Hukum Pidana.

Undang-undang Nomor 39 Tahun 1999 Tentang Hak Asasi Manusia. 